\title{
WELLBEING IN RURAL AREAS OF LITHUANIA: FINDINGS FROM THE EUROPEAN SOCIAL SURVEY
}

Gintarė VAZNONIENE், Business and Rural Development Research Institute, Faculty of Bioeconomy Development, Vytautas Magnus University, Universitetas str. 10-408, Akademija, Kaunas distr., Lithuania, gintare.vaznoniene@ vdu.It (corresponding author) Gabija JARAŠIŪNAITĖ-FEDOSEJEVA, Department of Psychology, Faculty of Social Sciences, Vytautas Magnus University, Jonavos str. 66-303, Kaunas., Lithuania, gabija.jarasiunaite-fedosejeva@ vdu.lt

\begin{abstract}
This article reports on the evaluation of the wellbeing of rural people in Lithuania. Literature analysis and empirical findings suggest that research on wellbeing has received scant attention, especially at the local level in Lithuania. Although, to date, some research has been carried out on other specific factors of wellbeing such as belonging to a particular social group, wellbeing in the city, or wellbeing related to job environment, etc., far too little attention has been paid to socio-demographic variables. These limitations call for a more comprehensive discussion and analysis of the situation of a wellbeing and its tendencies in rural areas. The aim of this rese arch is to evaluate the relationship between wellbeing and socio-demographic characteristics of residents of rural areas in Lithuania. Statistical calculations evaluating the wellbeing of rural people were made by using data from the last Round 8 of the European Social Survey. The findings show that the wellbeing of rural people is related to socio- demographic characteristics. People living in big cities of Lithuania rate their happiness higher than those living in towns or small cities and rural areas; residents of rural areas of Lithuania who live with children are happier and more satisfied with life than those living without children at household grid; weak and negative, but statistically significant, correlations between happiness and age, and satisfaction with life and age were observed; younger residents in rural areas of Lithuania are happier and more satisfied with life in comparison to older ones; the longer people study, the happier and more satisfied with life they are; divorced are less happy and satisfied with life than those who have never been married as well as those who are legally married or are widows/widowers; people who study are happier and more satisfied with life than those who work, are unemployed or retired.
\end{abstract}

Keywords: Wellbeing, rural areas, happiness, satisfaction with life, European social survey.

\section{INTRODUCTION}

The concept of wellbeing has received a lot of scholarly attention in a range of different fields, which approach it from different perspectives. Scientists interested in research on wellbeing (Veenhoven, 2009; Brezzi, 2014; King et al., 2014) emphasize its importance in human life despite where people live because wellbeing covers various domains of life: social, material, cultural, environmental, etc. The perception of what wellbeing is, is usually very subjective as wellbeing can be perceived in different ways. Wellbeing includes key components of a good life (for an individual, social group, community, region, country, etc.) or focuses on what people feel/think about their life. Accordingly, wellbeing also covers the evaluation of a person's happiness and satisfaction with his/her life. From the sociological point of view (Veenhoven, 2009), wellbeing is a social construct because, due to various circumstances, it can be formed every day by separate individuals or even groups; it has become an integral component of scientific priority; it includes a lot of different domains of life; it can be static or dynamic; etc. Human personal experience, life events, choices, and lifestyle can be factors determining good or bad life and greater or lesser happiness. Detailed aspects of the multidimensionality of wellbeing reveal the difficulty in describing it unambiguously; however, it has also been recognized that the understanding of wellbeing enables scientists to identify not only the state or changes of wellbeing but also limitations or interference that hinder higher wellbeing.

Both international organizations (e.g. OECD; UN) and various scientists (Steuer, Marks, 2008; Annoni et al., 2012; Kozlova et al., 2015) have recognised that research on wellbeing is much more meaningful when it focuses on a certain territory (rural, urban area) and people living in it. The importance of such research to society in different territorial levels (international, national, regional, local) may differ, and it has been observed that research on wellbeing is regarded as not being so significant in relation to some territories, especially in the rural context (Weckroth, Morrison, 2014; Mello, Brezzi, 2015). It should be noted that Lithuania also lacks research on territorial wellbeing. Even though studies on wellbeing have been conducted in Lithuania, the territorial aspect has obviously not received proper attention. Thus, the wellbeing of rural people lacks scholarly investigation. Moreover, different characteristics and aspects of the wellbeing of rural people seem to be neglected by the society. To fill the above-mentioned gaps, the research in this article focuses on a territorial unit - rural areas. This also implies that a better understanding of the wellbeing of rural people and its socio-demographic characteristics can reveal tendencies of the development of rural areas in Lithuania, i.e. whether it is

Copyright (C) 2019 The Authors. Published by Vytautas Magnus University. This is an open-access article distributed under the terms of the Creative Commons Attribution License (CC-BY 4.0), which permits unrestricted use, distribution, and reproduction in any medium, provided the original author and source are credited. 
more positive or negative. In the light of the above, the following research problem was formulated: What sociodemographic characteristics are related to the wellbeing of rural people? The object of the research is wellbeing in rural areas of Lithuania. The aim of the research is to evaluate the relationship between the wellbeing and socio-demographic characteristics of residents of rural areas in Lithuania. The research is based on mixed theoretical and empirical research methods.

\section{THEORETICAL PART}

\section{Conceptualisation of wellbeing}

Wellbeing is a multidimensional concept, and the understanding of this concept depends on various things. Authors (Gasper, 2005; Brezzi, 2014; Taylor, 2015; EUROFOUND, 2019) analysing wellbeing agree that it is a complex concept. Wellbeing can have different forms (King et al., 2014; Taylor, 2015; Atkinson et al., 2017) and depends on the level at which it is analysed (e.g. local/regional/national wellbeing). It should be pointed out that research on wellbeing has been conducted in various sciences related to humans, e.g. medicine, gerontology, psychology sciences and other social sciences. However, there is a lack of the definitional clarity of the concept of wellbeing, and very often, this concept has been closely associated or used interchangeably with the following concepts: the quality of life, a better living, a standard of living, welfare, happiness, satisfaction with life, or social progress, etc. The analysis of literature (Steuer, Marks, 2008; Vaznoniené, Vaznonis, 2011; Atkinson et al., 2017) reveals that very often definitions of wellbeing overlap, synonyms are used to refer to it, definitions supplement each other or are very similar. Forgeard et al. (2011) and Anand (2016) emphasize that wellbeing is best understood as a multifaceted phenomenon that can be assessed by measuring a wide array of subjective (individual, internal aspects: e.g. health status, family status, physical condition, etc.; personal perceptions, opinion) and objective (external: e.g. material conditions, work environment, conditions of a living place, etc.; using statistical data) constructs. Subjective wellbeing, according to Diener (2006), is often assumed to be synonymous with happiness. Taylor $(2015$, p. 75, 76) also highlights that, although different theories disagree about what constitutes wellbeing, it is obvious that all positive things that happen and affect human life can raise the level of wellbeing or feeling of happiness. According to the researcher, wellbeing consists of various elements or so called "subjective goods," such as happiness, pleasant life events, higher income, or positive relationships, etc. Thus, the evaluation of happiness is also one of the possible ways to determine how people perceive their life: good or bad. This suggests that human wellbeing can be affected by various internal and external factors, but in subjective evaluations of wellbeing, socio-demographic factors are rated as significant factors because they disclose a personal perception of what is a good life for an individual person and also show opportunities that a person has in his/her life. Despite this approach, there is a range of personal or subjective factors important for personal or individual wellbeing, which almost always include the following (Gasper, 2005; Weckroth, Morrison, 2014; Atkinson et al., 2017): life style, positive and negative life events, choices and alternatives, health, etc. Assessments of individual wellbeing can also be based on very small or big achievements of an individual, his/her feelings about life, emotional and functional components (Forgeard et al., 2011; Anand, 2016). The authors of the present article follow the conception of Atkinson et al. (2017), where individual subjective wellbeing (or the wellbeing of rural people) is understood as individuals' perceptions and feelings about different aspects of their life, in relation to socio- demographic factors/characteristics. Thus, the above insights suggest that the evaluation of wellbeing is difficult and can be different. This paper focuses on subjective evaluations of individual wellbeing in rural areas and the authors of the paper refrain from objective evaluation. The above-presented insights are also supported by the newest EUROFOUND (2019) report “Is Rural Europe Being Left Behind?", which highlights the fact that rural communities have distinctive patterns of economic development and social life as young people tend to move to big towns and cities for education and work, declining population and ageing; all these things have knock-on effects on the quality of life of rural dwellers. It was found that rural people do less well than the urban population; and the focus was also placed on the wellbeing of rural people by emphasizing evaluations of satisfaction with life.

\section{Wellbeing in Lithuania and its rural areas}

The concept of wellbeing or the quality of life is still often described by many Lithuanian scientists as complex and ambiguous. They also highlight the complexity of the evaluation of this phenomenon and the search for methodological approaches. While searching for scientific publications related to the wellbeing / quality of life of the Lithuanian population, several main topics were observed. Research on wellbeing at the national level is still a new field of research, so it is clear that, over the last decade, different Lithuanian researchers have explored mostly theoretical aspects of wellbeing and the quality of life. Starkauskiene (2011) analyzed the factors of the quality of life and presented a model of complex evaluation. Dumbliauskienè and Jarmalavičienè (2012) attempted to define methodological problems in the complex evaluation of the quality of life. Krutulienè (2012) also tried to clarify the concept of the quality of life by revealing its essence and its relation to other terms of a good life. Servetkienè (2013) analyzed and provided a detailed description of approaches and opportunities for the multidimensional assessment of the quality of life, identifying critical areas. The latter works are very similar in content, and they are more theoretical and methodological in nature. In addition, the notions of the quality of life and wellbeing used in publications are often misleading, or researchers focus their attention on objective or subjective wellbeing in particular.

Another group of studies on wellbeing is related to the assessment of the wellbeing of specific social groups (most often referred to as elderly/retired people, or people with various illnesses). Vaznonienè (2010) studied the socio-economic factors of the subjective quality of the life of elderly people. Staškute (2014) explored the concept of the health-related quality 
of life, its monitoring methods and evaluation and its significance in health policy. The author points out that such research is also important for public health monitoring, as it reflects how happy the society is about its health or how it values its quality of life. Jenciūtè et al. (2015) examined the health-related quality of life of older people. It is evident from recent research that it is aspects of wellbeing related to health and the elderly that are of interest to researchers because of the aging population in Lithuania and the importance of health as a factor in personal wellbeing for the society as a whole.

The analysis of works by Lithuanian scientists related to the wellbeing of the Lithuanian population revealed that the territorial dimension is mostly neglected, especially in the rural urban context, although socio-demographic factors remain important in many research results. This is also evidenced by the results of recent research, which should be discussed in greater detail. Pranckevičienè et al. (2015) focused on differences in the wellbeing of Lithuanians and emigrants. The authors carried out a comparative analysis of indicators of the wellbeing of Lithuanians and emigrants, taking into account social and demographic factors. They found that the wellbeing of emigrants was significantly influenced by socio-demographic characteristics, such as higher overall wellbeing, the psychological and social wellbeing of women, higher social wellbeing, higher emotional wellbeing of the partner, and skilled work associated with higher evaluations of overall wellbeing.

The wellbeing of the rural population in Lithuania has received little scholarly attention. Rèklaitiene et al. (2009) conducted research on the quality of life of the Lithuanian population focusing on the impact of the residence in the country and socio-economic status. The authors found that, in comparison to the life in urban areas, the residence in rural areas negatively affects the overall wellbeing, psychological domain, the level of independence and spirituality of people living there. Vaznonienè and Vaznonis (2011) examined subjective wellbeing in rural areas, drawing attention to the importance of the subjective evaluation of wellbeing and its significance. Kuliešis and Pareigiene (2014) discussed changes in the quality of life of the Lithuanian elderly rural population in 2001-2011 with the focus on living conditions. They found that living conditions influence the wellbeing of rural people and made an observation that living conditions in rural areas are still lower in comparison to the living conditions of the urban population. They showed that the aging of the population in Lithuanian rural areas is a serious issue, which affects the vitality of rural areas, the importance of provided services and socialisation of rural people. Kriaučiūnas (2018) analysed tendencies in the development of Lithuanian rural areas and their underlying reasons in the context of the wellbeing of the population. The author focused on how rural transformations affect the wellbeing of the rural population in the overall development of rural areas, without taking into consideration specific aspects or domains of wellbeing. He also showed that, over time, transformations in rural areas influence the quality of socio-demographic characteristics of local people.

In view of all that has been mentioned so far, it can be stated that research on the wellbeing of the current population in Lithuania has specific features. Accordingly, the following question may be raised: Why is it important to study the wellbeing of the rural population? The following facts call for the analysis of the phenomenon of wellbeing:

- the exiting studies are fragmented, inconsistent;

- research has been carried out by a few scientists;

- studies aim to explore the concept of wellbeing or the quality of life in general;

- more research has been conducted on objective rather than subjective wellbeing;

- some researchers use well-established methodologies to measure wellbeing, while others develop their own science-specific methods;

- it is not easy to collect official statistics on objective wellbeing (there are no clearly developed/distinguished indicators);

- it is difficult to unambiguously define what constitutes the wellbeing of the rural population;

- some researchers use specific methodologies of research on wellbeing (e.g. from World Health Organisation). Literature analysis provide evidence that participants in the research on the wellbeing in Lithuania represent some of the main social groups while others are excluded. These include the elderly (retired) or the sick, urban residents, and people living in specialized institutions. Some studies focus on the assessment of wellbeing from a gender perspective. It is worth noting that the territorial dimension in highlighting sections of the wellbeing of urban - rural population is very rare. A small number of scientific inquiries into the wellbeing of rural people fosters scientific interest in this field. Moreover, both theoretical and empirical findings on wellbeing can contribute to a better understanding of what makes rural people happy, or what factors determine their wellbeing.

\section{RESEARCH METHODOLOGY}

The present study employs mixed research methodology. The methods of literature analysis and synthesis were applied for theoretical studies. In order to evaluate the wellbeing of residents of rural areas in Lithuania, the data from the last Round 8 of the European Social Survey in 2017 were used. The European Social Survey (further the ESS) is one of the biggest survey conducted in Europe and has a special issue including questions on wellbeing, happiness, and satisfaction with life, which can be evaluated according to various aspects, where high quality data on different aspects of wellbeing for more than 30 European countries are provided. Sampling and its key principles of implementation in the ESS are guided by the requirements outlined in the official ESS internet page (Sampling: https://www.europeansocialsurvey.org/methodology/ess_methodology/sampling.html). The sample for rural areas according to the Round 8 was 585 respondents.

As wellbeing is a multidimensional concept, it was important for the authors of the present paper to define the concept of a rural area in the context of the ESS. For this research, the territorial aspect, as given in the ESS methodology, 
is divided into the following groups: a big city, suburbs or outskirts of a big city, a town or a small city, a country village, a farm or home in the countryside. Such apportionment enables the comparison between separate territories and the exploration of differences existing among them. The authors of the article define rural areas as a country village plus a farm or home in the countryside, which shows wellbeing at the local level.

The respondents of the survey were asked how happy they were and evaluated their happiness from 0 to 10 points in Likert scale, where "0" meant "Extremely unhappy" and "10" - "Extremely happy". Satisfaction in life in general was also measured from 0 to 10 points in Likert scale, where "0" meant "Extremely dissatisfied" and "10" - "Extremely satisfied". The authors of this article took into consideration the following socio-demographic variables: gender, age, years of full-time education completed, family situation (whether the respondent lives with a husband/wife/partner or without, whether children live at home or not, and marital status), the main activity and feelings about household income.

The ESS data were analyzed using IBM Statistical Package for Social Sciences (SPSS 21). Normality tests showed that the data related to the evaluation of happiness and satisfaction with life were close to a normal distribution, so pairedsamples Student $t$ test was used to evaluate differences between the evaluations of happiness and satisfaction with life made by residents of rural areas of Lithuania according to their gender and family situation (whether the respondent lives with a husband/wife/partner or without; whether the respondent lives with children at household grid or without them). One-Way ANOVA with Post Hoc Bonferroni correction were used to evaluate differences between the evaluations of happiness and satisfaction with life made by residents of rural areas of Lithuania according to their legal marital status, main activity and feelings about household income. The wellbeing (happiness and satisfaction with life) in cities and rural areas of Lithuania in 2017 was also compared by using One-Way ANOVA with Post Hoc Bonferroni correction. To evaluate the relationship between happiness, satisfaction with life and age, as well as years of full-time education completed, we used Spearmen correlation coefficient. All the data were weighted by using post-stratification weight including design weight. The chosen statistical significance level was 0.05 .

\section{RESEARCH RESULTS}

The research results revealed some important data about the relation between wellbeing and socio-demographic characteristics. The comparison of wellbeing (happiness and satisfaction with life) according to the living area (comparing the situation in cities and rural areas) of Lithuania in 2017 is presented in Figure 1.

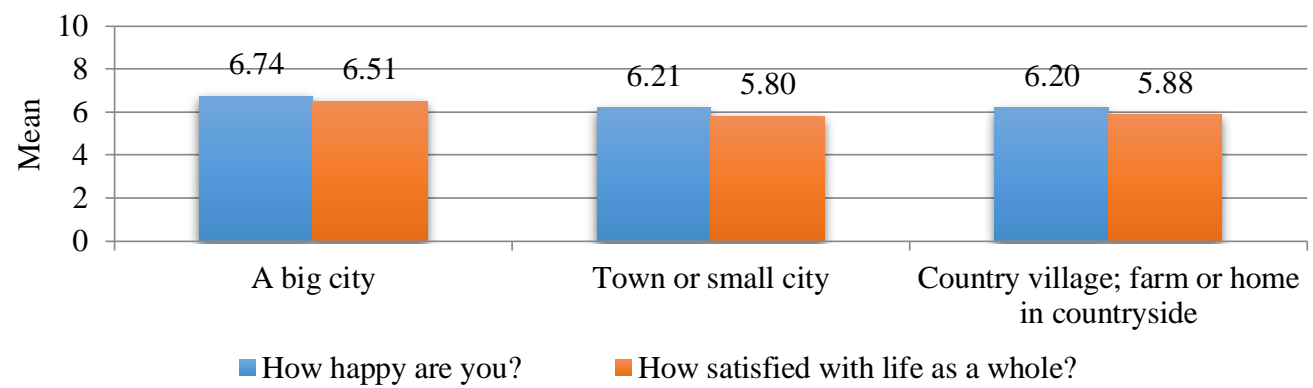

Figure 1. The comparison of wellbeing (happiness and satisfaction with life) according to the living area in Lithuania in 2017

The results show that people living in big cities of Lithuania rate their happiness higher than those living in towns or small cities and rural areas (country villages; farms or homes in the countryside) $(\mathrm{p}<0.05)$. People living in big cities are also more satisfied with life than people living in towns or small cities as well as residents of rural areas $(\mathrm{p}<0.05)$.

The comparison of wellbeing (happiness and satisfaction with life) of residents of rural areas of Lithuania according to their gender, living with a husband/wife/partner and living with children in 2017 is presented in Table 1.

Table 1. The comparison of wellbeing (happiness and satisfaction with life) of residents of rural areas of Lithuania according to their gender, living with a husband/wife/partner and living with children in 2017

\begin{tabular}{|c|c|c|c|c|c|c|c|c|c|}
\hline \multirow{2}{*}{\multicolumn{2}{|c|}{ Sociodemographic characteristics }} & \multicolumn{4}{|c|}{ How happy are you? } & \multicolumn{4}{|c|}{ How satisfied with life as a whole? } \\
\hline & & Mean & $\mathrm{t}$ & df & $\mathrm{p}$ & Mean & $\mathrm{t}$ & df & $\mathrm{p}$ \\
\hline \multirow{2}{*}{ Gender } & Male & 6.22 & \multirow{2}{*}{0.143} & \multirow{2}{*}{575} & \multirow{2}{*}{0.886} & 5.87 & \multirow{2}{*}{-0.179} & \multirow{2}{*}{576} & \multirow{2}{*}{0.858} \\
\hline & Female & 6.19 & & & & 5.90 & & & \\
\hline \multirow{2}{*}{$\begin{array}{c}\text { Lives with } \\
\text { husband/ wife/ } \\
\text { partner }\end{array}$} & $\begin{array}{l}\text { Respondent lives } \\
\text { with husband/ } \\
\text { wife/ partner }\end{array}$ & 6.18 & \multirow[t]{2}{*}{0.234} & \multirow[t]{2}{*}{571} & \multirow[t]{2}{*}{0.815} & 5.80 & \multirow[t]{2}{*}{-1.253} & \multirow[t]{2}{*}{329.459} & \multirow[t]{2}{*}{0.211} \\
\hline & Does not & 6.22 & & & & 6.04 & & & \\
\hline \multirow[t]{2}{*}{$\begin{array}{c}\text { Children living at } \\
\text { home or not }\end{array}$} & $\begin{array}{c}\text { Respondent lives } \\
\text { with children at } \\
\text { household grid }\end{array}$ & 6.55 & \multirow[t]{2}{*}{3.762} & \multirow[t]{2}{*}{571.530} & \multirow[t]{2}{*}{$<0.001$} & 6.11 & \multirow[t]{2}{*}{2.456} & \multirow[t]{2}{*}{570.416} & \multirow[t]{2}{*}{0.014} \\
\hline & Does not & 5.95 & & & & 5.71 & & & \\
\hline
\end{tabular}

The analysis of the data suggests that neither gender nor the fact whether the respondent lives with a husband/wife/partner or without him/her are related to the evaluation of their happiness and satisfaction with life ( $\mathrm{p}>0.05$ ). 
However, residents of rural areas of Lithuania who live with their children are happier and more satisfied with life than those who live without children at household grid $(\mathrm{p}<0.05)$.

The correlations of wellbeing (happiness and satisfaction with life), age and years of full-time education completed of residents of rural areas of Lithuania in 2017 are presented in Table 2.

Table 2. The correlations of wellbeing (happiness and satisfaction with life), age and years of full-time education completed of residents of rural areas of Lithuania in 2017

\begin{tabular}{|c|c|c|c|c|}
\hline Sociodemographic characteristics & \multicolumn{3}{|c|}{ How happy are you? } & \multicolumn{2}{c|}{ How satisfied with life as a whole? } \\
\cline { 2 - 5 } & $\mathrm{r}$ & $\mathrm{p}$ & $\mathrm{r}$ & $\mathrm{p}$ \\
\hline Age & -0.259 & $\boldsymbol{< 0 . 0 0 1}$ & -0.325 & $<\mathbf{0 . 0 0 1}$ \\
\hline Years of full-time education completed & 0.132 & $\mathbf{0 . 0 0 2}$ & 0.122 & $\mathbf{0 . 0 0 3}$ \\
\hline
\end{tabular}

The results show weak and negative, but statistically significant, correlations between happiness and age, and satisfaction with life and age. The younger residents of rural areas of Lithuania are, the happier and more satisfied with life they are $(p<0.05)$. However, the older residents of rural areas of Lithuania are, the less happy and satisfied with life they are $(\mathrm{p}<0.05)$. The results also revealed weak and positive, but statistically significant, correlations between happiness and years of full-time education completed, and satisfaction with life and years of education. The longer residents of rural areas of Lithuania study, the happier and more satisfied with life they are $(\mathrm{p}<0.05)$. Contrarily, the fewer years respondents spent on their education, the less happy and satisfied with life they are $(\mathrm{p}<0.05)$.

The comparison of wellbeing (happiness and satisfaction with life) of residents of rural areas of Lithuania according to their legal marital status, main activity and household income in 2017 is provided in Table 3.

Table 3. The comparison of wellbeing (happiness and satisfaction with life) of residents of rural areas of Lithuania according to their legal marital status, main activity and household income in 2017

\begin{tabular}{|c|c|c|c|c|c|c|c|c|c|}
\hline \multirow{2}{*}{\multicolumn{2}{|c|}{ Sociodemographic characteristics }} & \multicolumn{4}{|c|}{ How happy are you? } & \multicolumn{4}{|c|}{ How satisfied with life as a whole? } \\
\hline & & Mean & $\mathrm{df}$ & $\mathrm{F}$ & $\mathrm{p}$ & Mean & $\mathrm{df}$ & $\mathrm{F}$ & $\mathrm{p}$ \\
\hline \multirow{4}{*}{$\begin{array}{l}\text { Legal } \\
\text { marital } \\
\text { status }\end{array}$} & Legally married & 5,90 & \multirow{4}{*}{3} & \multirow{4}{*}{9.540} & \multirow{4}{*}{$<0.001$} & 6,27 & \multirow{4}{*}{3} & \multirow{4}{*}{10.491} & \multirow{4}{*}{$<0.001$} \\
\hline & $\begin{array}{l}\text { Legally divorced/ civil union } \\
\text { dissolved }\end{array}$ & 4,84 & & & & 4,98 & & & \\
\hline & Widowed/civil partner died & 5,59 & & & & 6,05 & & & \\
\hline & $\begin{array}{l}\text { None of these (NEVER } \\
\text { married or in legally registered } \\
\text { civil union) }\end{array}$ & 6,63 & & & & 6,72 & & & \\
\hline \multirow{4}{*}{$\begin{array}{c}\text { Main } \\
\text { activity last } \\
7 \text { days }\end{array}$} & $\begin{array}{c}\text { Paid work } \\
\end{array}$ & 6,46 & \multirow{4}{*}{3} & \multirow{4}{*}{23.574} & \multirow{4}{*}{$<0.001$} & 6,20 & \multirow{4}{*}{3} & \multirow{4}{*}{34.024} & \multirow{4}{*}{$<0.001$} \\
\hline & Education & 7,73 & & & & 7,76 & & & \\
\hline & Unemployed $^{1}$ & 5,14 & & & & 4,89 & & & \\
\hline & Retired & 5,79 & & & & 5,26 & & & \\
\hline \multirow{4}{*}{$\begin{array}{c}\text { Feeling } \\
\text { about } \\
\text { household's } \\
\text { income } \\
\text { nowadays }\end{array}$} & $\begin{array}{l}\text { Living comfortably on present } \\
\text { income }\end{array}$ & 7,79 & \multirow{4}{*}{3} & \multirow{4}{*}{32,334} & \multirow{4}{*}{$<0.001$} & 8,30 & \multirow{4}{*}{3} & \multirow{4}{*}{27,464} & \multirow{4}{*}{$<0.001$} \\
\hline & Coping on present income & 6,09 & & & & 6,40 & & & \\
\hline & Difficult on present income & 5,24 & & & & 5,61 & & & \\
\hline & $\begin{array}{l}\text { Very difficult on present } \\
\text { income }\end{array}$ & 4,95 & & & & 5,13 & & & \\
\hline
\end{tabular}

The results show that legal marital status is related to the evaluation of happiness and satisfaction with live of residents of rural areas of Lithuania. People who are divorced are less happy and satisfied with life than those who have never been married as well as those who are legally married or are widows/widowers $(p<0.05)$.

The analysis of the data revealed that the main activity of residents of rural areas of Lithuania is also related to their evaluation of happiness and satisfaction with life. People who study are happier and more satisfied with life than those who work, are unemployed or retired $(\mathrm{p}<0.05)$. The ones who have a paid job are also happier and more satisfied with life than those who are unemployed or retired $(\mathrm{p}<0.05)$.

In further analysis, feelings about one's household income were also found to be related to happiness and satisfaction with life of residents of rural areas. The respondents who stated that they are living comfortably with present income are happier and more satisfied with life than those who said that they are coping on present income, as well as those who stated that they are difficult or very difficult on present income $(p<0.05)$. The respondents who stated that they are coping on present income are happier and more satisfied with life than those who noted that they are difficult or very difficult on present income $(\mathrm{p}<0.05)$.

\section{CONCLUSIONS AND DISCUSSION}

1. Wellbeing is a multidimensional concept and its definition is not straightforward. Wellbeing covers various domains of life (social, economic, cultural, emotional, etc.) and is affected by various internal and external factors. It has been acknowledged that wellbeing can be subjective (or individual, including internal aspects: e.g. health status, family

\footnotetext{
${ }^{1}$ Unemployed (unemployed, looking for job; unemployed, not looking for job; permanently sick or disabled; housework, looking after children).
} 
status, physical condition, etc.; personal perceptions, opinion) and objective (external: e.g. material conditions, work environment, conditions of living place etc.; using statistic data); however, evaluation methods of wellbeing differ.

2. Literature analysis revealed that the territorial aspect with the emphasis on the wellbeing of rural people has received scant attention or has not been the field of interest in social sciences in Lithuania. In general, there is a lack of research on the topic chosen for the analysis in the present paper. This shows that, in comparison to other social groups, the wellbeing of rural people has not been closely and consistently examined. However, the awareness factors affecting the wellbeing of rural people can facilitate our understanding of what makes rural people happy or what shapes their wellbeing.

3. Socio-demographic characteristics of rural people is one of the groups of characteristics that influence their wellbeing and also reveal the quality of the rural population. The empirical research revealed interesting findings on how socio-demographic characteristics are related to the wellbeing of rural people. People who live in big cities of Lithuania rate their happiness higher (and they are also more satisfied with life) than those who live in towns or small cities and rural areas. Neither gender, nor the fact whether the respondent lives with a husband/wife/partner or without him/her are related to the evaluation of his/her happiness and satisfaction with life; however, those who live with children are happier and more satisfied with life than those who live without children. People who are divorced are less happy and satisfied with life than those who have never been married as well as those who are legally married or are widows/widowers. Statistically significant correlations between happiness and age, happiness and years of full-time education completed, and satisfaction with life and age, satisfaction with life and years of education were found. This suggests that the longer residents of rural areas of Lithuania study, the happier and more satisfied with life they are. The younger residents of rural areas of Lithuania are, the happier and more satisfied with life they are in comparison to older residents. People who study are happier and more satisfied with life than those who work, are unemployed or retired. The ones who have a paid job are also happier and more satisfied with life than those who are unemployed or retired.

Acknowledgment. Preparation of the article and it's publication was supported by the Research Council of Lithuania project No. VS3 Implementation of membership in ESS.

\section{REFERENCES}

1. Anand P. 2016. Happiness, well-being and human development: The case for subjective measures. Background Paper. UNDP Human Development Report. Available at http://hdr.undp.org/sites/default/files/anand template_rev.pdf (accessed on 12/08/2019)

2. Annoni P., Weziak-Bialowolska D., Dijkstra L. 2012. Quality of Life at the sub-national level: an operational example for the EU. Reference Report by the Joint Research Centre of the European Commission.

3. Atkinson S., Bagnall A.M., Corcoran R., South J. 2017. What is Community Wellbeing? Conceptual review. Available at https://www.researchgate.net/publication/320020559_What_is_Community_Wellbeing_Conceptual_Review (accessed on $12 / 08 / 2019)$

4. Brezzi M. 2014. How's life in your region? Measuring regional and local well-being for policy making. OECD Directorate for Public Governance and Territorial Development. 4 August Global Forum UN-GGIM.

5. Diener E. 2006. Guidelines for national indicators of subjective well-being and ill-being. Journal of Happiness Studies, 7(4), pp. 397-404. https://doi.org/10.1007/s10902-006-9000-y

6. Dumbliauskienė M., Jarmalavičienė S. 2012. Gyvenimo kokybės kompleksinio vertinimo metodologinès problemos. Geografijos metraštis, 45, pp. 3-16.

7. EUROFOUND. 2019. Is rural Europe being left behind? European Quality of Life Survey 2016, Publications Office of the $\begin{array}{llll}\text { European } \quad \text { Union, Available at } & \text { Luxbourg. }\end{array}$ https://www.eurofound.europa.eu/sites/default/files/ef publication/field ef document/ef18024en.pdf (accessed on 10/08/2019)

8. Forgeard M. J. C., Jayawickreme E., Kern M., Seligman M. E. P. 2011. Doing the right thing: Measuring wellbeing for public policy. International Journal of Wellbeing, Vol. 1(1), pp. 79-106. https://doi.org/10.5502/ijw.v1i1.15

9. Gasper D. 2005. Subjective and objective well-being in relation to economic inputs: puzzles and responses. Review of Social Economy, Vol. 63, Iss. 2, pp. 177 - 206. https://doi.org/10.1080/00346760500130309

10. Jenciūtė V., Žuravliova T., Razbadauskas A., Mažrimas A. 2015. Pagyvenusių žmonių su sveikata susijusi gyvenimo kokybė. Visuomenès sveikata, Priedas Nr. 1, pp. 51-55. (In Lithuanian)

11. King M. F., Reno V. F., Novo E. M. L. M. 2014. The Concept, Dimensions and Methods of Assessment of Human Well-Being within a Socioecological Context: A Literature Review. Social Indicators Research., Vol. 116, Iss. 3, pp. 681-698. https://doi.org/10.1007/s11205-013-0320-0

12. Kozlova, O.A., Gladkova T.V., Makarova M.N., Tukhtarova E. Kh. 2015. Methodological approach to measure the quality of life of the region's population. R-Economy, No. \#2, pp. 115-125. https://doi.org/10.15826/recon.2015.2.011

13. Kriaučiūnas E. 2018. Lietuvos kaimiškų teritorijų apgyvenimas: erdvinès transformacijos ir gyventojų gerovè. Geografijos metraštis, No. 51, pp. 3-24. (In Lithuanian)

14. Krutulienè, S. 2012. Gyvenimo kokybė: sąvokos apibrèžimas ir santykis su gero gyvenimo terminais. Kultūra ir visuomenè, 3 (2), pp. 117-130. (In Lithuanian)

15. Kuliešis G., Pareigienė L. 2014. Pagyvenusių Lietuvos kaimo gyventojų gyvenimo kokybės pokyčiai $2001-2011$ metais. Management Theory and Studies for Rural Business and Infrastructure Development, Vol. 36. No. 4, pp. 871-880. https://doi.org/10.15544/mts.2014.082 
16. Mello L., Brezzi M. 2015. Measuring well-being in regions and cities: How can it help improving policy-making? Available at: https://whatworkswellbeing.files.wordpress.com/2015/01//se-seminar-brezzi-de-mello.pdf (accessed on $15 / 06 / 2019)$

17. OECD 2014. How's life in your region? Measuring regional and local well-being for policy making, OECD Publishing.

18. Pranckevičienė A., Žardeckaitė-Matulaitienė K., Markšaitytė R., Endriulaitienė A., Šeibokaitė,L. 2015. Lietuvoje ir užsienyje gyvenančių lietuvių gerovės skirtumai. Visuomenès sveikata, Vol. 2(69), pp. 94-101. (In Lithuanian)

19. Rèklaitienė R., Bacevičienè M., Andrijauskas K. 2009. Quality of life in Lithuanian population: the impact of country residence and socio-economic status. Central European Journal of Medicine, Vol. 4(4), pp. 476-482. https://doi.org/10.2478/s11536-009-0058-X

20. Servetkienė V. 2013. Gyvenimo kokybès daugiadimensis vertinimas, identifikuojant kritines sritis. Daktaro disertacija, Vilnius. (In Lithuanian)

21. Starkauskienė V. 2011. Gyvenimo kokybès veiksniai ir jos kompleksinio vertinimo modelis. Daktaro disertacija. Kaunas. (In Lithuanian)

22. Staškute I. 2014. Su sveikata susijusios gyvenimo kokybės samprata, stebėsenos ir vertinimo metodai bei reikšmė sveikatos politikoje. Health Policy and Management, No. 1(6), pp. 7-19. https://doi.org/10.13165/SPV-14-1-6-01 (In Lithuanian)

23. Steuer N., Marks N. 2008. Local Wellbeing: Can We Measure It? Department for Communities and Local Government. Available at: https://youngfoundation.org/wp-content/uploads/2013/02/Local-Wellbeing-Can-we-Measure-it-September2008.pdf (accessed on 15/06/2019).

24. Taylor T. E., 2015. The markers of wellbeing: A basis for a theory-neutral approach. International Journal of Wellbeing, 5(2), pp. 75-90. https://doi.org/10.5502/ijw.v5i2.5

25. Vaznonienė G. 2010. Subjektyvios pagyvenusių žmonių gyvenimo kokybės socialiniai ekonominiai veiksniai. Sociologija. Mintis ir veiksmas, No. 2(27), pp. 186-204. https://doi.org/10.15388/SocMintVei.2010.2.6113 (In Lithuanian)

26. Vaznonienè G., Vaznonis B. 2011. Subjective Wellbeing Research in Rural Areas // Conference proceedings "Rural development 2011: the fifth international scientific conference", Vol. 5, b. 1, pp. 279-284.

27. Veenhoven, R. 2009. Well-Being in Nations and Well-Being of Nations. Is There a Conflict Between Individual and Society? Social Indicators Research, Vol. 1, pp. 5-21. https://doi.org/10.1007/s11205-008-9323-7

28. Weckroth M., Morrison P. 2014. Economic growth, density, and subjective well-being in Finnish regions: The paradox of affluence in geographic context. Regional Studies Associations European Conference. Conference papers. At Izmir, Turkey. Available at: http://www.regionalstudies.org/uploads/Mikko_Weckroth_and_Philip_Morrison_PDF.pdf (accessed on $15 / 06 / 2019)$ 